\title{
Epidemiological aspects of uterine myomas among nulligest women at the general reference hospital of Panzi in Democratic Republic of the Congo
}

\author{
Sifa Balungwe ${ }^{1 *}$, Raha Maroyi ${ }^{1}$, Mpakanyi Joyeux¹, Mukango Omari², \\ Mulongo Philémon ${ }^{3}$, Nakiyo Olivier ${ }^{3}$
}

\author{
${ }^{1}$ Department of Obstetrics and Gynecology, Panzi Hospital, Bukavu, Democratic Republic of The Congo \\ ${ }^{2}$ Independent Consultant, Bukavu, Democratic Republic of The Congo \\ ${ }^{3}$ Department of Midwifery, ISTM-Bukavu, Bukavu, Democratic Republic of The Congo
}

Received: 25 January 2021

Revised: 07 March 2021

Accepted: 08 March 2021

\section{*Correspondence:}

Dr. Sifa Balungwe,

E-mail: sifabalu@gmail.com

Copyright: (C) the author(s), publisher and licensee Medip Academy. This is an open-access article distributed under the terms of the Creative Commons Attribution Non-Commercial License, which permits unrestricted non-commercial use, distribution, and reproduction in any medium, provided the original work is properly cited.

\begin{abstract}
Background: Myomas appear early in young women. The objective of this study was to evaluate the frequency of uterine myomas among nulligest women screened at the Panzi Hospital in South Kivu.

Methods: A cross-sectional study was conducted among women aged 20-35 years during the period from 01 August 2018 to 01 August 2019. Women were recruited for screening after their informed consent. Informed consent was sought prior to participation in the study. The main data collection tools were the survey questionnaire. An individual survey questionnaire was used for data collection, laboratory records and trans-abdominal ultrasound. Descriptive statistics were calculated.

Results: The median age of the women was 25 years. Positive myotomy was noted in $45.9 \%$ of cases. Submucosal and subperitoneal localization was predominant (48.6\%). Young, unmarried, overweight women were the most common. The mean age of the menarche was $11.83 \pm 1.48$ years. The consumption of red meat, green vegetables and alcohol was more noted. Exposure to the sun and wearing half-covered clothing were also noted. Abdominal and lumbar pain were the main symptoms observed. The majority used lightening products.

Conclusions: The study notes the early appearance of uterine myomas among women aged 20-35 years in our environment. A mass evaluation and screening of this population is necessary to establish prevention and the best management.
\end{abstract}

Keywords: Epidemiology, Myomas, Nulligestes, Panzi hospital

\section{INTRODUCTION}

Myomas are the most common benign tumors in gynecology and affect $20-50 \%$ of women of childbearing age its impact on fertility is controversial in a literature difficult to analyze. ${ }^{1}$ They grow under the influence of several factors in particular, hormones through growth factors and vitamin D is topical. It is extremely important since $20 \%$ of women in their 30 s and $50 \%$ of women in their 50s are carriers of myomas. ${ }^{1}$ This pathology affects women between the ages of 30 and 50, but with hormone replacement therapy, its frequency increases after the age of 50. Estro-progestogens do not seem to increase the occurrence of a myoma and instead there is a decrease in the risk. Black women are affected 3 to 4 times more often, and clinically, their frequency increases. ${ }^{1,2}$ These factors do not exactly explain the risk of myoma occurrence and its almost impossible prevention, hence their association and the search for potential new factors associated with 
them that contribute to the development and progression of myomas. ${ }^{2,3}$ Research has shown in vitro that vitamin D $[(25(\mathrm{OH}) \mathrm{D}]$ can inhibit the proliferation of uterine leiomyomas. ${ }^{4-7}$ The active metabolite of vitamin $\mathrm{D}$ has been shown to inhibit cell proliferation and extracellular matrix production in fibrous tissue culture and to reduce the volume of myomas in Esker rats and prevent the growth of human fibroid cells in laboratory cultures.

Studies show that vitamin D deficiency is one of the predictive factors for the occurrence of uterine myoma, and that a large part of the population is deficient, especially the elderly. ${ }^{7,8}$ In the literature, few studies have focused on vitamin D in young people specifically aged 20 to 35 years. Recent epidemiological studies have shown an association between levels of exposure to risk factors and the occurrence of myoma. ${ }^{8,9}$ Vitamin D deficiency is a hot topic because of its globalization, affecting more than a billion people worldwide and its consequences such as the occurrence of myomas. However, there is little research in Africa, with only a few groups working on the problem, and it is not possible to get a true picture of the problem.

The objective of this study is to evaluate the frequency of uterine fibroids among women aged 20-35 years in order to contribute to the prevention of early onset of uterine fibroids in nulligestes between 20 and 35 years in our community.

\section{METHODS}

We conducted a cross-sectional study at the General Reference Hospital of Panzi in South Kivu. This study was conducted among nulligest women from 01 August 2017 to 01 August 2019. The selection of the 412-nulligest women was occasional after their informed consent. The women participating in the study were sensitized at the gynecology and obstetrics department of the Panzi hospital. We received the women's agreement to the collection and completion of the survey questionnaire. Ultrasound scans were performed by the laboratory of Panzi hospital. A trans-abdominal ultrasound was done systematically. The analysis of the collected data was carried out by statistical package for the social sciences (SPSS) 23 software. The quantitative variables were resummarized by the median and their range of deviation and the qualitative variables were presented in the form of frequency tables. Ethical principles were respected throughout this study. The anonymity and confidentiality of the data collected were strictly respected.

\section{RESULTS}

The median age was $25(20-35)$ years and $60 \%$ of the nulligest women were between 20 and 25 years old, $63.6 \%$ came from the health area of Ibanda, (90.3)\% were single, (65.2)\% were university students, (97.3)\% had an average standard of living, (45.4)\% were Catholics, (44.2)\% were overweight (Table 1).
Table 1: General characteristics of study population.

\begin{tabular}{|ll|}
\hline Parameters & n $(\%)$ \\
\hline Age range (years) & \\
\hline $20-25$ & $247(60.0)$ \\
\hline $26-30$ & $112(27.2)$ \\
\hline $31-35$ & $53(12.9)$ \\
\hline Median (min-max) & $25(20.35)$ \\
\hline Place of origin & $14(3.4)$ \\
\hline Bagira & $262(63.6)$ \\
\hline Ibanda & $33(8.0)$ \\
\hline Kadutu & $103(25.0)$ \\
\hline Out of town & $372(90.3)$ \\
\hline Civil status & $40(9.7)$ \\
\hline Single & \\
\hline Married & $6(1.5)$ \\
\hline Education status & $137(33.3)$ \\
\hline Primary & $269(65.2)$ \\
\hline Secondary & \\
\hline University & $5(1.2)$ \\
\hline Standard of living & $401(97.3)$ \\
\hline Low & $6(1.5)$ \\
\hline Average & $14(3.4)$ \\
\hline High & $187(45.4)$ \\
\hline Religion & $176(42.7)$ \\
\hline Muslim & $35(8.5)$ \\
\hline Catholic & $3(0.7)$ \\
\hline Protestant & $195(47.3)$ \\
\hline Others & $32(7.3)$ \\
\hline Body mass index & \\
\hline Lean (<18.5) & \\
\hline Normal (18.5-24.9) & \\
\hline Overweight (25-29.9) & \\
\hline Moderate obesity (30-34.9) & \\
\hline Morbid obesity (>40) & \\
\hline
\end{tabular}

Table 2: History of uterine myomas among nulligestes.

\begin{tabular}{|ll|}
\hline Variables & $\mathbf{n}(\%)$ \\
\hline History of uterine myomas & \\
\hline No & $223(54.1)$ \\
\hline Yes & $189(45.9)$ \\
\hline Previous history (n=189) & $162(85.8)$ \\
\hline Familiar 1st degree & $11(5.8)$ \\
\hline Personal & $16(8.4)$ \\
\hline Familiar 1st degree+personal & \\
\hline Age of menarch (years) & $11.83 \pm 1.48$ \\
\hline Means \pm standard deviation & \\
\hline Cycle abnormalities & $170(41.3)$ \\
\hline None & $7(1.7)$ \\
\hline Polymenorrhea & $177(43.0)$ \\
\hline Dysmmenorrhea & $57(13.8)$ \\
\hline Dysmenorrhea+polymenorrhea & $1(0.2)$ \\
\hline Spaniomenorrhea & \\
\hline
\end{tabular}


We note the history of uterine myomas in $45.9 \%$ of women, among them, 162 women $(85.8 \%)$ had a firstdegree family history. The mean age of menarch was $11.83 \pm 1.48$ years (Table 2 ).

The results of the Table 3 show that the diets of the nulligest women were dominated by the consumption of red meat, green vegetables and alcohol. Concerning the dress code, we noted that most of the women wore partially covered clothing. Most women spent less than one hour in the sun. Forty-one percent of the women used lightening products. $36.9 \%$ had a fair skin tone and $32 \%$ had a black skin tone (Table 3 ).

Pelvic pain (51.2\%), low back pain (49.8\%) and bleeding between periods among $(14.6 \%)$ women were noted in first place (Table 4). Positive myotomy was noted in 189 women or $45.9 \%$. Moreover, in $48.6 \%$ the myomas were localized submucosal and subperitoneal (Table 5).

Table 3: Diet, clothing and sun exposure among nulligests.

\begin{tabular}{|ll|}
\hline Variables & n (\%) \\
\hline Diet & $317(76.9)$ \\
\hline Red meat consumption & $289(70.1)$ \\
\hline Green vegetable consumption & $140(34.0)$ \\
\hline Dairy products & $223(54.1)$ \\
\hline Alcohol intake & $174(42.2)$ \\
\hline Fish consumption & $71(17.2)$ \\
\hline Egg consumption & \\
\hline Dress code & $143(34.7)$ \\
\hline Fully hedged & $260(63.1)$ \\
\hline Partially hedged & $9(2.2)$ \\
\hline Equipped clothing & $358(86.8)$ \\
\hline Time of exposure to the run (hour) \\
\hline$<1$ & $54(13.1)$ \\
\hline$>1$ & $242(58.7)$ \\
\hline Use of lightening products & $170(41.3)$ \\
\hline No & \\
\hline Yes & $132(32.0)$ \\
\hline Body complexion & $152(36.9)$ \\
\hline Black & $128(31.1)$ \\
\hline Clear & \\
\hline Dark black &
\end{tabular}

Table 4: Symptoms in nulligest women.

\begin{tabular}{|ll|}
\hline Variables & n $(\%)$ \\
\hline Symptoms & \\
\hline Lumbar pain & $205(49.8)$ \\
\hline Pelvic pain & $211(51.2)$ \\
\hline Bleeding between periods & $60(14.6)$ \\
\hline Feeling of abdominall mass & $1(0.2)$ \\
\hline Sensation of vaginal mass & $1(0.2)$ \\
\hline Urinary difficulty & $1(0.2)$ \\
\hline
\end{tabular}

Table 5: Pelvic ultrasound results for myoma and their location.

\begin{tabular}{|ll|}
\hline Variables & n $(\%)$ \\
\hline Pelvic ultrasound for myoma & \\
\hline Negative & $223(54.1)$ \\
\hline Positive & $189(45.9)$ \\
\hline Location of the myoma $(\mathbf{n = 1 8 9 )}$ & \\
\hline Submucous & $92(48.6)$ \\
\hline Subperitoneal & $92(48.6)$ \\
\hline Subserous & $2(1.0)$ \\
\hline Cervical interstitial & $1(0.5)$ \\
\hline Intracavitary & $1(0.5)$ \\
\hline Intracorporal & $1(0.55)$ \\
\hline
\end{tabular}

\section{DISCUSSION}

The results of our study showed that the frequency of uterine myomas was $45.9 \%$ defined by positive myotomy among women. In addition, in $48.6 \%$ the myomas were localized submucosal and subperitoneal. Our results do not corroborate those found in France by Fernandez et al in 2014, in a sample of 2498 women 220 women had presented a uterine fibroid, a prevalence of $8.8 \% .^{10}$

This difference can be explained by the level of sample size between these two studies. Our results also differ from those of Djibril in 2008, which found a $32 \%$ frequency of uterine fibroids and interstitial localization was the most frequent with $44 \% .^{11}$

In our Panzi series, we noted that $44.2 \%$ of women with no weight were overweight. These results are similar to those found by Marshall et al who found a significant association between obesity and myoma growth. ${ }^{8}$

In our study, we found that $45.9 \%$ of the women had a history of uterine myomas, among them, 162 women or $85.8 \%$ had a first-degree family history. Our results are consistent with those found by Vikhlyaeva et al, who demonstrated a family predisposition and showed that fibroids were twice as frequent when there was a family history of fibroids in the first degree, and in the series of Lumbiganon et al, who showed that the risk is four times higher when there is a family history of fibroids. ${ }^{9,12}$

In our series, we found that the mean age of menarche was $11.83 \pm 1.48$ years. These results are consistent with the literature, as it has been shown that the age of menarche or first menstrual period is a factor significantly associated with fibroids younger than 12 years. ${ }^{7}$ Our results are similar to those of Djibril in 2008, who noted that $46.88 \%$ of women had their periods stopped before the age of 15 years. ${ }^{9}$

In our study, we noted pelvic pain $(51.2 \%)$, lumbar pain (49.8\%), and bleeding between periods among (14.6\%) women. Compared to the French series of Fernandez et al in 2014, one hundred and sixty-three women (73.7\%) had 
bleeding, whether or not associated with pain, and 58 $(26.3 \%)$ had isolated pain. 110 women $(49.7 \%)$ rated their pain as severe or extremely severe and $178(80.6 \%)$ felt embarrassed in their daily lives. ${ }^{10}$ These results are similar to those found in our Panzi series despite some differences in the percentages.

Our results are almost similar to those found by Djibril in 2008, who had noted pelvic pain in 55 women or $27.5 \%$, menorrhagia in 34 women $17 \%$ menorrhagia. ${ }^{11}$ Contrary to our results, in the series of Cham et al in 2013 in Lubumbashi, the risk of finding uterine fibroids is five times lower in women under 30 years old. ${ }^{7}$

\section{Limitations}

As the design of the study is descriptive, it was difficult to identify the factors associated with the early onset of myomas in nulligest patients.

\section{CONCLUSION}

The frequency of uterine myomas in nulliparous women aged 20-35 years is very high in our community, $45.9 \%$ in a young population. Forty-eight percent of the myomas were localized submucosal and subperitoneal. We noted that the majority of the women were still single, sixty-five percent were academics and forty-four percent were overweight. The history of uterine myomas was noted in $45.9 \%$ of the women, among whom $85.8 \%$ had a firstdegree family history. The diets of nulligest women were dominated by red meat consumption, green vegetables and alcohol consumption. We noted that most of the women wore their clothes completely covered and spent less than one hour in the sun. We also noted pelvic pain, lower back pain and bleeding between periods among women with no menstrual periods.

\section{ACKNOWLEDGMENTS}

Authors would like to thank the team of Gynecology and Obstetrics of Panzi Hospital who supported in the production of this work and the patients who willingly accepted to be part of this study.

Funding: No funding sources Conflict of interest: None declared

Ethical approval: The study was approved by the Institutional Ethics Committee

\section{REFERENCES}

1. Rongieres C. Épidémiologie du fibrome utérin: facteurs de risques et fréquence. Impact en Santé
Publique: Recommendations pour la pratique clinique: Prise en charge des fibromes utérins. J Gynécol Obstét Biol Reprod. 1999;28(7):701-6.

2. Okogbo FO, Ezechi OC, Loto OM, Ezeobi PM. Uterine Leiomyomata in South Western Nigeria: a clinical study of presentations and management outcome. Afr Health Sci. 2011;11(2):271-8.

3. Claude R. Épidémiologie, facteurs de risque et symptomatologie des myomes utérins. Méd Reprod. 2009;11(2):118-22.

4. Wallach EE, Vlahos NF. Uterine myomas: an overview of development, clinical features, and management. Obstet Gynecol. 2004;104(2):393-406.

5. Ross RK, Pike MC, Vessey MP, Bull D, Yeates D, Casagrande JT. Risk factors for uterine fibroids: reduced risk associated with oral contraceptives. $\mathrm{Br}$ Med J (Clin Res Ed). 1986;293(6543):359-62.

6. Parazzini F, Negri E, La Vecchia C, Chatenoud L, Ricci E, Guarnerio P. Reproductive factors and risk of uterine fibroids. Epidemiology. 1996;440-2.

7. Cham LC, Mwembo TNA, Chenge MF, Kabulu KA, Otshudiongo TS , Kalenga MK. Etude des facteurs de risque associés à l'apparition des fibromyomes utérins à Lubumbashi, Congo. Revue Médicale des Grands Lacs. 2013;2(1):38-45.

8. Marshall LM, Spiegelman D, Manson JE, Goldman MB, Barbieri RL, Stampfer MJ, Willett WC, Hunter DJ. Risk of uterine leiomyomata among premenopausal women in relation to body size and cigarette smoking. Epidemiology. 1998;9(5):511-7.

9. Rongières C. Épidémiologie du fibrome utérin : facteurs de risque et fréquence. Impact en santé publique. J Gynecol Obstet Biol Reprod. 1999;28:701-6.

10. Fernandez H, Chabbert Buffet N, Allouche S. Prévalence du fibrome utérin en France et impact sur la qualité de vie à partir d'une enquête menée auprès de 2500 femmes de 30-55ans [Prevalence of uterine fibroids in France and impact on quality of life: results of a survey among 2500 women between 30-55 years]. J Gynecol Obstet Biol Reprod (Paris). 2014;43(9):721-7.

11. Magassouba D. Etude épidemio-clinique et thérapeutique du fibrome utérin dans le service de gynécologie obstétrique du CHU du point-g. Diss. Thèse de doctorat/Méd. Bamako, Mali. 2008.

12. Vikhlyaeva EM, Khodzhaeva ZS, Fantschenko ND. Familial predisposition to uterine leiomyomas. Int $\mathbf{J}$ Gynecol Obstet. 1995;51(2):127-31.

Cite this article as: Balungwe $\mathrm{S}$, Maroyi R, Joyeux M, Omari M, Philémon M, Olivier N. Epidemiological aspects of uterine myomas among nulligest women at the general reference hospital of Panzi in Democratic Republic of the Congo. Int J Reprod Contracept Obstet Gynecol 2021;10:1759-62. 